\title{
Analisis Fenomenologi Perilaku Komunikasi Etnis Tionghoa Di Kota Batam
}

\author{
Angga Intueri Mahendra Purbakusuma \\ Universitas Amikom Yogyakarta, Indonesia \\ angga_intuery@amikom.ac.id
}

\begin{abstract}
Abstrak
Adaptasi dalam berinteraksi antar etnis menjadi suatu keharusan di kota yang heterogen dan multi etnis seperti Kota Batam. Upaya menjalin komunikasi antar etnis yang efektif dapat mendorong keharmonisan hubungan suatu masyarakat. Masyarakat etnis Tionghoa di Kota Batam masih memiliki stigma sebagai etnis pendatang, meskipun mereka sudah lama hidup di Indonesia. Catatan sejarah membuktikan bahwa hubungan antara etnis Tionghoa dengan berbagai etnis lain di Indonesia sudah terjalin sejak lama dan memberikan kontribusi yang cukup penting dalam kehidupan sosial dan ekonomi masyarakat khususnya di kota Batam. Penelitian ini bertujuan untuk mengetahui fenomena perilaku komunikasi (verbal dan non verbal) antara etnis Tionghoa dengan etnis lainnya di kota Batam, serta perilaku komunikasi antar etnisnya. Pendekatan penelitian kualitatif interaktif dengan analisis fenomenologi dengan objek penelitian di lingkungan organisasi PSMTI dan BMTI kota Batam. Hasil penelitian menunjukan bahwa perilaku komunikasi verbal antar pribadi masyarakat etnis Tionghoa di dalam lingkungan keluarga pada umumnya banyak menggunakan bahasa etnis masingmasing suku. Sementara penggunaan bahasa Indonesia digunakan untuk pendidikan anak serta sebagai pelengkap dan substitusi beberapa konteks bahasa yang tidak ditemukan padanannya dalam bahasa etnis. Di lingkungan organisasi baik PSMTI maupun BMTI, penggunaan bahasa Indonesia baik secara lisan maupun tertulis menjadi secara lebih dominan. Berbagai bentuk komunikasi non verbal masyarakat etnis Tionghoa, antara lain meliputi penggunaan simbol warna merah, artefak berupa bangunan rumah ibadah dan patung, bahasa tubuh seperti gerakan mengepalkan kedua tangan serta bentuk komunikasi non verbal lainnya.
\end{abstract}

Kata Kunci: Perilaku komunikasi, Etnis tionghoa, Analisis fenomenologi.

\begin{abstract}
Adaptation in inter-ethnic interactions is a necessity in a heterogeneous and multi-ethnic city such as Batam City. Efforts to establish effective inter-ethnic communication can promote harmonious relations in a society. The Chinese ethnic community in Batam City still has the stigma of being an ethnic immigrant, even though they have lived in Indonesia for a long time. Historical records prove that the relationship between the Chinese ethnic group and various other ethnicities in Indonesia has been established for a long time and has made quite an important contribution to the social and economic life of the community, especially in the city of Batam. This study aims to determine the phenomenon of communication behavior (verbal and non-verbal) between ethnic Chinese and other ethnic groups in Batam city, as well as communication behavior between ethnic groups. An interactive qualitative research approach with phenomenological analysis with the object of research in the PSMTI and BMTI organizations in Batam City. The results showed that the interpersonal verbal communication behavior of the Chinese ethnic community in the family environment generally uses the ethnic languages of each tribe. Meanwhile, the use of Indonesian is used for children's education as well as as a complement and substitute for several language contexts where no equivalent is found in ethnic languages. In both PSMTI and BMTI organizations, the use of Indonesian both orally and in writing is becoming more dominant. Various forms of non-verbal communication for the Chinese ethnic community include the use of red symbols, artifacts in the form of houses of worship and statues, body language such as clenching fists and other forms of non-verbal communication.
\end{abstract}

Keywords: communication behavior, Chinese ethnicity, phenomenological analysis. 


\section{PENDAHULUAN}

Badan Pusat Statistik (BPS) Kota Batam mencatat jumlah etnis Tionghoa di Kota Batam sebanyak 6,28\% dari total populasi penduduk di Kota Batam yang berjumlah 1.236.399 jiwa. Jumlah tersebut berada diurutan kelima setelah etnis Jawa, Melayu, Batak, dan Minangkabau ${ }^{1}$. Meski data kependudukan di Indonesia menunjukkan banyaknya etnis pendatang lain seperti Arab dan India, stereotipe non pribumi terhadap etnis Tionghoa di Indonesia masih cukup kental daripada etnis yang lain. Bahkan dalam kasus tertentu, misalnya seperti di Yogyakarta yang menerapkan peraturan daerah tentang etnis keturunan (Tionghoa) tidak bias menguasai hak atas tanah sebagai hak milik, menjadi satu bukti bahwa masih ada pandangan ketidak setaraan antar penduduk di Indonesia yang multi etnis.

Seperti layaknya etnis-etnis lain yang tinggal di Kota Batam, kehadiran masyarakat etnis Tionghoa dalam kelompok masyarakat di Kota Batam kota Batam memberikan dampak dalam bidang ekonomi, dampak sosial dan budaya. Satu sisi kehadiran masyarakat etnis Tionghoa dalam komunitas masyarakat mendapatkan pengakuan dan penerimaan serta dianggap memperkaya keragaman budaya, di sisi lain berkembang asumsi serta kekhawatiran akan adanya potensi bentrok sosial serta penolakan yang dapat menyebabkan berbagai polemik sosial budaya di masyarakat. Hal tersebut dikarenakan adanya pandangan bahwa etnis Tionghoa merupakan etnis pendatang dan bukan penduduk asli Indonesia atau yang biasa disebut Pribumi. Pandangan tersebut berdampak pada sikap diskriminatif terhadap masyarakat etnis Tionghoa, hal ini sangat terasa terutama pada masa sebelum reformasi tahun 1998.

Pengakuan terhadap etnis Tionghoa sudah diakui oleh masyarakat etnis lain, namun adanya pemikiran bahwa etnis Tionghoa merupakan etnis yang ekslusif menimbulkan ketimpangan atau kecemburuan sosial terutama di bidang ekonomi. Berdasar pengamatan dapat diketahui bahwa dalam perilaku keseharian, masyarakat etnis Tionghoa menjalin komunikasi yang baik dengan sesama etnis. Sementara dengan etnis lainnya, perilaku masyarakat etnis Tionghoa tidak seperti perilaku yang ditunjukan kepada sesama etnis tersebut. Besar kemungkinan hal ini merupakan bentuk pengeksklusifan masyarakat etnis Tionghoa di kota Batam.

Beberapa perilaku lain yang menunjukan perbedaan perlakuan juga ditunjukan oleh masyarakat etnis Tionghoa pada dunia pekerjaan. Seperti pada lowongan pekerjaan. Banyak

\footnotetext{
1 Dinas Kependudukan Kota Batam, (2015). Jumlah Penduduk Kota Batam 2015: Lampiran Data Jumlah Penduduk Berdasarkan Kecamatan. skpd.batamkota.go.id/kependudukan/data-kependudukan.html. Oktober, 15, 2015.
} 
perusahaan yang dimiliki oleh etnis Tionghoa ini lebih mengutamakan etnis Tionghoa yang menguasai bahasa mandarin. Padahal untuk realitas dunia pekerjaan, persyaratan tersebut sebenarnya bukan menjadi syarat prioritas. Karena sebenarnya tidak semua perusahaan membutuhkan tenaga kerja yang terampil serta menguasai bahasa mandarin. Artinya kedekatan etnis masih menjadi prioritas utama bagi perusahaan atau badan usaha yang dimiliki oleh etnis Tionghoa. Jika menggunakan paradigma kritis perilaku seperti ini dapat dikatakan sebagai perilaku diskriminatif yang dilakukan oleh masyarakat etnis Tionghoa terhadap etnis lain di Kota Batam.

Merujuk pandangan yang menyatakan bahwa komunikasi antar pribadi yang dilakukan oleh mereka yang berbeda latar belakang kebudayaan ${ }^{2}$, maka hubungan antarbudaya melibatkan simbol-simbol baik verbal maupun non verbal. Simbol tersebut memiliki makna yang disepakati bersama yang cenderung dapat memiliki perbedaan antarbudaya yang satu dengan budaya lain nya. Misalnya saja, ekspresi wajah, sikap dan gerak-gerik, suara, anggukan kepala dan lain nya. Bentuk perilaku komunikasi yang menjadi fokus dalam penelitian ini ialah komunikasi verbal serta non verbal.

Keberhasilan komunikasi banyak ditentukan oleh kemampuan komunikasi memberi makna terhadap pesan yang diterimanya. Semakin besar kemampuan memberi makna pada pesan yang diterimanya, semakin besar pula kemungkinan komunikan memahami pesan tersebut, sebaliknya, mungkin saja seorang komunikan banyak menerima pesan, tetapi ia tidak memahami makna pesan tersebut karena kurang mampu menafsirkan pesan tersebut. Prinsip ini juga berlaku pada komunikasi antarbudaya dimana tantangan yang dihadapi dalam proses komunikasi tidaklah mudah.

Ketika beberapa individu melakukan interaksi dengan baik, maka komunikasi yang terjalin juga akan baik pula. Perilaku komunikasi antarbudaya antara etnis Tionghoa dan etnis lainya di kota Batam, memiliki hubungan yang saling timbal balik, artinya saling membutuhkan satu sama lain. Lalu bagaimana bentuk perilaku komunikasi masyarakat etnis Tionghoa di kota Batam saat ini? apakah sudah mampu menjawab tantangan-tantangan komunikasi antarbudaya seperti yang telah disebutkan?. Hal ini menjadi topik yang menarik untuk dipelajari bagi peneliti.

Perilaku komunikasi etnis Tionghoa di kota Batam yang menjadi kajian dalam penelitian ini merupakan suatu fenomena sosial. Disebut fenomena sosial karena perilaku komunikasi merupakan bentuk interaksi sosial yang bersifat nyata dan dapat dirasakan

\footnotetext{
${ }^{2}$ Samovar; Porter dan McDaniel, (2010). Komunikasi Lintas Budaya (Edisi 7). Salemba Humanika, Jakarta. Hal.13.
} 
dengan pengindraan. Fenomenologi bertujuan untuk menginterpretasikan tindakan sosial kita dan orang lain sebagai sesuatu yang dapat dimaknai serta dapat merekonstruksi kembali turunan makna (makna yang digunakan saat berikutnya) dari tindakan yang bermakna pada komunikasi intersubjektif individu dalam kehidupan sosial ${ }^{3}$.

Model penelitian fenomenologi dianggap sebagai model yang tepat dalam melakukan penelitian perilaku komunikasi etnis Tionghoa di kota Batam. Karena fenomena sosial yang dapat diamati secara nyata dengan melakukan pendekatan langsung ke dalam lingkungan subjek untuk menggali informasi yang kuat sebagai dasar penjelasan atas esensi fenomena yang diteliti. Perilaku komunikasi masyarakat etnis Tionghoa di kota Batam yang dalam hal ini dapat dilihat dari bagaimana bentuk-bentuk komunikasi verbal serta non verbal masyarakat etnis Tionghoa akan difokuskan pada dua organisasi etnis Tionghoa yang ada di Batam, yaitu Paguyuban Sosial Marga Tionghoa Indonesia (PSMTI) dan Barisan Muda Tionghoa Indonesia (BMTI). Serta bagaimana komunikasi yang terjalin antara masyarakat etnis Tionghoa dengan masyarakat etnis lainnya di kota Batam. Maka penelitian ini membahas lebih lanjut tentang fenomena perilaku komunikasi (verbal dan non verbal) antara etnis Tionghoa dengan etnis lain di kota Batam.

\section{TINJAUAN PUSTAKA}

\section{Etnis Tionghoa}

Istilah etnik menunjuk pada suatu kelompok tertentu yang karena kesamaan ras, agama, asal-usul bangsa, ataupun kombinasi dari kategori tersebut terikat pada sistem nilai budayanya ${ }^{4}$. Sedangkan definisi Etnis Tionghoa, jika merujuk pada pendapat Trianisa adalah etnis perantauan atau pendatang dari negeri Cina yang datang ke Indonesia dengan tujuan berdagang maupun berimigrasi. Salah satunya berasal dari dua provinsi di Cina daratan yaitu Fukien dan Kwangtung. Suku- suku bangsa dari daerah tersebut adalah Hokkien, Teo-Chiu, Hakka dan Kanton. Berdasarkan kesimpulan diatas dapat disimpulkan bahwa etnis Tionghoa adalah suku bangsa perantau yang berasal di daerah negara Cina yang datang ke Indonesia dengan tujuan berimigrasi ataupun berdagang.

Vasanty dalam Koentjoningrat membagi etnis Tionghoa dalam dua golongan yaitu ${ }^{5}$ :

\footnotetext{
${ }^{3}$ Sudarmanti. Rini. 2006. "Memahami "Fenomenologi" Kesadaran Intersubjectif Aldfred Schutz". Jakarta: PT Gramedia. Hal.47.

${ }^{4}$ Barth, Fredrik. (1970). Introduction. Dalam Fredrik Barth dkk, Ethnic Group and Boundaries: The Social Organization of Culture Difference. Bergen - Oslo. Universiets Forlaget.

${ }^{5}$ Koentjaraningrat (2007). Manusia dan Kebudayaan Di Indonesia . Djambatan, Jakarta.
} 
1. Etnis Tionghoa Peranakan. Etnis Tionghoa Peranakan adalah seorang etnis Tionghoa yang lahir di Indonesia dan hasil dari perkawinan campuran antara orang Tionghoa asli dengan orang Indonesia, etnis Tionghoa Peranakan yang dalam banyak unsur kehidupan dan fisiknya sudah menyerupai orang Indonesia asli.

2. Etnis Tionghoa Totok. Etnis Tionghoa totok adalah seseorang etnis Tionghoa yang bukan hanya lahir di negara Tiongkok tetapi bisa juga lahir di Indonesia. Etnis Tionghoa totok yang ada di Indonesia kulturasi budaya nya masih sama seperti yang berada di negara Cina yang mana belum bisa berbahasa Indonesia tetapi berbicara bahasa Hokkien asli atau bahasa asalnya. Ciri-ciri fisiknya masih sama seperti orang Tionghoa negara asalnya.

\section{Perilaku Komunikasi}

\section{Komunikasi Verbal dan Nonverbal}

Sebuah interaksi yang dilakukan manusia tidak terlepas dari penggunaan bahasa dalam berkomunikasi. Bahasa diartikan sebagai seperangkat kata yang disusun secara berstruktur sehingga menjadi suatu kalimat yang mengandung makna. Fungsi bahasa yang mendasar bagi manusia adalah untuk menamai atau menjuluki objek, orang, dan peristiwa ${ }^{6}$. Proses komunikasi verbal tidak hanya bagaimana kita menggunakan bahasa dan berbicara dengan orang lain, namun juga bagaimana cara kita berpikir dan mengembangkan makna kata-kata yang kita gunakan. Akan tetapi komunikasi tidak hanya bisa diungkapkan melalui pesan-pesan verbal saja, melainkan juga dengan melalui pesan-pesan non verbal yang berupa simbol-simbol. Simbol yang digunakan dalam komunikasi bukan saja simbol verbal yang berupa kata-kata tapi juga menggunakan simbol yang berupa gambar, grafik, dan simbolsimbol lainnya yang merupakan simbol nonverbal.

Secara sederhana komunikasi nonverbal adalah komunikasi yang tidak menggunakan kata-kata melainkan semua isyarat yang memiliki makna. Komunikasi nonverbal adalah komunikasi yang dilakukan secara sengaja ataupun secara spontan oleh seseorang. Komunikasi nonverbal mencakup semua rangsangan (kecuali rangsangan verbal) dalam suatu setting komunikasi, yang dihasilkan oleh individu dan penggunaan lingkungan oleh individu, yang mempunyai nilai pesan potensial bagi pengirim atau penerima.

Jadi definisi ini mencakup perilaku yang disengaja juga tidak disengaja sebagai bagian dari peristiwa komunikasi secara keseluruhan, kita banyak mengirim pesan nonverbal

\footnotetext{
${ }^{6}$ Riswandi, Ilmu Komunikasi. ed. pertama. Yogyakarta: Graha Ilmu, 2009. Hal.59.
} 
tanpa menyadari bahwa pesan-pesan tersebut bermakna bagi orang lain. Komunikasi nonverbal seringkali dipergunakan untuk menggambarkan perasaan, emosi. Komunikasi nonverbal dapat memperkuat dan melengkapi komunikasi verbal ${ }^{7}$.

Komunikasi nonverbal ini biasanya ditunjukkan dalam bentuk perilaku berpenampilan, pakaian yang digunakan, atribut, gerakan dan postur tubuh, juga ditunjukkan dalam bentuk ekspresi wajah, kontak mata, dan sentuhan. Jadi definisi ini mencakup perilaku yang disengaja juga tidak disengaja sebagai bagian dari peristiwa komunikasi secara keseluruhan, kita banyak mengirim pesan nonverbal tanpa menyadari bahwa pesan-pesan tersebut bermakna bagi orang lain. Komunikasi nonverbal seringkali dipergunakan untuk menggambarkan perasaan, dan keadaan emosi seseorang. Sebagaimana kata-kata, kebanyakan isyarat nonverbal juga tidak universal, melainkan terikat oleh budaya, dipelajari, bukan bawaan. Pesan nonverbal membantu kita menafsirkan seluruh makna pengalaman komunikasi. Dalam hubungannya dengan perilaku verbal, perilaku nonverbal mempunyai fungsi-fungsi menurut Mulyana adalah sebagai berikut ${ }^{8}$ :

1. Perilaku nonverbal dapat mengulangi perilaku verbal.

2. Memperteguh, menekankan atau melengkapi perilaku verbal

3. Perilaku nonverbal dapat menggantikan perilaku verbal, jadi berdiri sendiri.

4. Perilaku nonverbal dapat meregulasi perilaku verbal.

5. Perilaku nonverbal dapat membantah atau bertentangan dengan perilaku verbal.

Komunikasi yang terjadi di kalangan pecinta kereta api tidak lepas dari komunikasi nonverbal, di dalam komunitas ataupun di lingkungannya, sarat dengan muatan pesan nonverbal, setidaknya hal tersebut tercermin dari perilaku mereka yang lebih menonjol lewat pakaian dan atribut lain yang digunakan yang berpotensial untuk ditafsirkan secara bebas. Simbol-simbol nonverbal memungkinkan dapat dipelihara autensitasnya sebagai sebuah identitas budaya atau komunitas tertentu.

\section{METODE PENELITIAN}

Analisis fenomenologi perilaku komunikasi etnis tionghoa di Kota Batam dilakukan dengan menggunakan pendekatan kualitatif deskriptif. Teknik yang digunakan dalam analisis makna-makna perilaku komunikasi ini menggunakan proses imaginative variation. Teknik ini digunakan untuk mencari makna-makna yang memungkinkan melalui penggunaan imajinasi, pembedaan berbagai macam bingkai referensi, pengelompokkan dan pembalikan, dan

\footnotetext{
${ }^{7}$ Mulyana, Dedi. (2005). Ilmu Komunikasi, Suatu Pengantar. Remaja Rosdakarya. Bandung. Hal 308.

${ }^{8}$ Mulyana, Dedi. (2005). Ilmu Komunikasi Suatu Pengantar. Remaja Rosdakarya. Bandung. Hal. 310.
} 
pendekatan phenomenon dari perspektif yang divergen, posisi, peran-peran, atau fungsi yang berbeda ${ }^{9}$. Tujuannya adalah untuk mencapai deskripsi struktural dari pengalaman, faktorfaktor yang mendasar dan mempengaruhi apa yang telah dialami. Dengan kata lain bagaimana pengalaman dari phenomenon menjadi yang seperti sekarang ini $^{10}$.

Langkah-langkah imaginative variation meliputi dalam penelitian ini diantaranya $\operatorname{adalah}^{11}$ :

a. Membuat sistematika dari berbagai kemungkinan semua makna yang tersusun yang mungkin menjadi dasar dari makna secara tekstural dalam komunikasi masyarakat Tionghoa di Kota Batam.

b. Mengenali tema-tema atau konteks-konteks sebagai dasar penyebab munculnya fenomena perilaku komunikasi masyarakat Tionghoa di Kota Batam.

c. Mempertimbangkan struktur secara keseluruhan yang dapat menyebabkan terjadinya pengambilan kesimpulan yang terlalu cepat pada perasaan dan pikiran yang berkaitan dengan phenomenon, seperti struktur waktu, ruang, perhatian yang hanya tertuju pada hal-hal yang utama, materiality, causality, hubungan dengan diri sendiri, atau hubungan dengan orang lain dalam perilaku komunikasi etnis Tionghoa di Kota Batam.

d. Mencari ilustrasi sebagai contoh yang dapat memberikan gambaran secara jelas mengenai struktur dari tema-tema yang tidak berubah dan memfasilitasi pengembangan deskripsi phenomenon yang struktural dalam perilaku komunikasi etnis Tionghoa di Kota Batam.

Langkah terakhir dari proses penelitian ini adalah integrasi fundamental dari deskripsi tekstural dan struktural fenomena perilaku komunikasi etnis Tionghoa di Kota Batam menjadi satu pernyataan sebagai esensi pengalaman dari phenomenon secara keseluruhan. Maka dari sini makna-makna dari fenomena komunikasi etnis Tionghoa di Kota batam dideskripsikandengan sintesis tekstural-struktural yang mendasar mewakili esensi waktu dan tempat tertentu dari sudut pandang peneliti, mengikuti studi imajinatif dan reflektif dari phenomenon.

\footnotetext{
${ }^{9}$ Nugrahaningsih, Putri. 2005. Analisis Perbedaan Perilaku Etis Auditor di KAP dalam Etika Profesi (Studi Terhadap Peran Faktor-Faktor Individual: Locus of Control, Pengalaman Kerja, Gender, dan Equity Sensitivity). Simposium Nasional Akuntansi VIII. Hal.26.

${ }^{10}$ Idem. Hal 27.

${ }^{11}$ Idem. Hal 29.
} 


\section{PEMBAHASAN}

Berdasarkan pada hasil observasi Observasi ini dilaksanakan pada tanggal 15 Januari sampai 16 Januari, berlokasi di Toa Pek Kong Windsor. Kelenteng yang dibangun pada tahun 1970 ini merupakan kelenteng yang memiliki banyak sejarah tinggi. Bangunannya didominasi warna merah serta terdiri dari beberapa bagian ruang persembahan. Dinding utama terdapat lukisan serta relief dewa-dewa. Masyarakat etnis Tioghoa yang dating kesini melakukan puji-pujian dalam memanjatkan doa kepada yang mereka percayai. Ketika mereka berinteraksi, Bahasa yang mereka gunakan adalah bahasa Tio Chiu dan Hokkien. Penjaga kelenteng juga dengan suka rela memberikan bantuan dan petunjuk bagi turis yang berkunjung di kelenteng ini.

Klenteng ini khusunya di ruang utamanya terdapat ruang tempat memanjatkan doa orang konghuchu, masyarakat etnis Tionghoa kota Batam ataupun yang berasal dari Negara lain seperti Malaysia dan Singapura ramai berkunjung ke kelenteng ini untuk memanjatkan doa serta meminta sedikit rejeki dalam doanya. Kelenteng ini juga sudah menjadi salah satu daftar untuk dikunjungi di kota Batam. Papan petunjuk kelenteng ini menggunakan tiga bahasa ,dalam bahasa mandarin, Indonesia dan Inggris. Bahasa Inggris digunakan untuk memudahkan para turis asing yang datang berkunjung ke kelenteng ini.

Kelenteng ini sering diadakan event- event dalam memperingati hari besar etnis Tionghoa, misalnya saja cap goh me, Imlek yang dirayakan dengan pertunjukan barongsai dan sembahyang bersama. Bangunan utama memiliki kolam kura-kura yang terletak di bagian belakang, terdapat belasan kura-kura yang dipelihara di kelenteng ini. Kolam kurakura ini juga terdapat satu kolam yang disampingnya terdapat tujuh patung putri yang sedang mandi ,dipercaya patung tersebut merupakan pengikut Dewi Kwan im.

Etnis Tionghoa dalam melakukan sembahyang adalah dengan berdiri sempurna, berlutut ketika perlu memohon. Jumlah hio yang dipakai juga ada aturannya, angka ganjil adalah un tuk sifat YANG sedangkan angka genap adalah untuk sifat YIN. Hio yang dipakai disesuaikan dengan kebutuhan, terhadap leluhur tidaklah harus selalu menggunakan sifat YIN. Bersembahyang harus selalu tulus dan hormat, harus memperlakukan altar dengan sakral, tidak boleh seenaknya. Berdoa yang benar, jangan selalu meminta hal-hal yang remeh. Memegang hio juga ada aturannya, bara api hio harus setara dengan titik tengah antara kedua alis. Hio dipegang tegak lurus.

Badan tegak lurus dan membungkuk mendalam sempurna saat member penghormatan. Tancap hio dengan tangan kiri, karena tangan kiri perlambangan YANG ,arti YANG disini adalah kita menghargai yang disembahyangi dengan pikiran positif. Tancap hio 
satu per satu ,hio ditancap setengah di dalam altar. Setelah acara sembahyang, etnis Tionghoa juga membakar uang kertas sebagai symbol penghormatan kepada leluhur.

Klelenteng ini juga akan dipasang lampion pada saat menjelang imlek nanti. Kelenteng ini dikelola oleh generasi muda mudi disini. Keakraban dirasa sangat terjalin di kelenteng ini. Apalagi turis yang berkunjung kesini pun ramah, mereka mengabadikan gambar di kelenteng tua ini. Berbagai artefak terdapat di kelenteng ini.

\section{Perilaku komunikasi verbal}

Berdasarkan pengamatan serta catatan pendukung data dari organisasi PSMTI, sesama masyarakat etnis Tionghoa di kota Batam lebih dominan menggunakan bahasa Tio ciu dalam berkomunikasi sehari-hari, baik itu dalam lingkungan internal mau pun berkomunikasi dengan yang berbeda sub etnis seperti Hokkien, Hakka, Kek dan lainnya. Sebagai contoh, cara berbicara orang Tionghoa yang seharusnya agak sedikit tegas kalau didengar pada saat menggunakan bahasa Hokkien yang dalam tingkatan bunyi atau intonasi yang berbeda tiap katanya. Tetapi ketika mereka telah berbaur dengan etnis lainnya maka orang Tionghoa berbicara menyesuaikan intonasi yang lebih lembut mengikuti logat setempat.

Selain itu, terjadinya pencampuran bahasa juga membuat tata cara masyarakat etnis Tionghoa berkomunikasi menjadi lebih mudah dengan etnis lainnya karena menggunakan bahasa yang sama dan saling mengerti. Ketika anak-anak muda melakukan pembicaraan dengan orang yang dianggap lebih tua, mereka akan sangat menghormati dan memperhatikan dengan seksama. Ketika diberikan kesempatan untuk berpendapat, mereka akan berbicara sesuai dengan apa yang mereka inginkan. Ini merupakan ciri masyarakat etnis Tionghoa yang mengeluarkan pendapat dengan terbuka. Walaupun berbeda sub etnis, sebenarnya pengucapan kata dalam bahasa Tio ciu agak mirip dengan bahasa hokkien, hanya saja dari dialek dan intonasinya berbeda. Bahasa Tio ciu terdengar lebih halus dibandingkan dengan bahasa Hokkien yang dalam intonasinya terdengar tegas.

Secara umum keluarga etnis Tionghoa di kota Batam rata-rata menggunakan bahasa daerah asal dari tempat mereka berasal untuk berkomunikasi di lingkungan keluarga. Penggunaan bahasa Tio ciu dirasa lebih mudah didengar serta dipahami dalam berkomunikasi antar pribadi maupun dengan etnis Tionghoa yang berbeda sub etnis. Komunikasi yang baik antara etnis Tionghoa dengan yang berbeda sub etnis dapat dibuktikan dengan suatu keadaan dimana keduanya saling membina hubungan yang baik dalam relasi kerja maupun dalam pertemanan. Komunikasi yang baik ini didukung oleh sikap toleransi serta faktor kebutuhan akan sosialisasi yang baik. Seperti yang dinyatakan oleh Deddy Mulyana, kode verbal adalah 
sebuah bahasa. Bahasa verbal adalah sarana untuk menyatakan fikiran, perasaan dan maksud dalam proses komunikasi.

Pembauran dalam berkomunikasi sudah bisa dirasakan dengan nyata. Komunikasi yang terbentuk pada masyarakat etnis Tionghoa dengan etnis lainnya di kota Batam, memberikan pengaruh dalam penggunaan bahasa. Beberapa etnis lainnya menggunakan bahasa Tio ciu untuk menyebutkan nilai mata uang, misalnya saja penggunaan kata goban' yang berarti lima puluh ribu serta kata cengli' yang berarti keberuntungan. Dalam lingkungan internal organisasi PSMTI masih menggunakan Bahasa campuran, misalnya saja etnis Tionghoa dalam rapat organisasi menggunakan empat bahasa, yakni bahasa Mandarin, Tio ciu, Hokkien, dan bahasa Indonesia . Rata-rata semua anggota bisa berbahasa Tio ciu, jadi bahasa yang digunakan di campur sesuai dengan kebutuhan. Pengucapan salam melalui telp menggunakan bahasa Indonesia. Pada proses wawancara ini berlangsung, narasumber juga menggunakan bahasa Indonesia untuk menjawab semua pertanyaan dari peneliti.

Hal serupa juga didapati dalam lingkungan internal organisasi BMTI, dalam rapat organisasi maupun dalam surat internal organisasi, bahasa yang digunakan adalah bahasa Indonesia. Organisasi BMTI merupakan organisasi yang mengedepankan sisi nasionalisme serta prularisme oleh karena itu sikap toleransi serta penggunaan bahasa Indonesia memang sudah menjadi kebiasaan di organisasi ini. Walaupun sudah terjadi pembauran dan pembelajaran bahasa, namun tidak semua masyarakat etnis Tionghoa bisa menerjemahkan arti pesan diluar dari bahasa etnis mereka. Kalangan usia yang disebut dengan senior hanya bisa berbicara dengan bahasa etnis mereka serta sangat sedikit sekali yang bisa berbahasa indonesia. Hal ini tentu saja menjadi pemicu tidak sampainya pesan yang dikomunikasikan oleh komunikan. Pesan yang disampaikan pun menjadi rancu.

\section{Perilaku Komunikasi Non Verbal}

Latar belakang budaya yang berbeda antara etnis Tionghoa dengan etnis lainnya di kota Batam memperkaya pengalaman berkomunikasi. Masyarakat etnis Tionghoa dalam berkomunikasi dengan masyarakat etnis lainnya awalnya memiliki kesulitan untuk memahami satu sama lainnya. Walaupun penggunaan bahasa Indonesia sudah banyak digunakan, namun ada saja bahasa Tio ciu yang sulit dijelaskan dengan bahasa Indonesia. Tidak mudah juga mengucapkan kata per kata yang jelas dalam bahasa Indonesia ketika logat bahasa daerah masih sangat kental dalam masyarakat etnis Tionghoa.

a. Bahasa Tubuh. Berdasarkan pengamatan peneliti, isyarat tangan yang menjadi kebiasaan masyarakat etnis Tionghoa seperti gerakan mengepal kedua telapak tangan pada saat 
memberikan ucapan salam di perayaan tertentu seperti tahun baru imlek. Selain isyarat tangan, peneliti juga mengamati adanya kebiasaan gerak kepala menunduk ketika bertemu dan memberi salam kepada orang yang lebih tua.

b. Paralinguistik (Parabahasa). Komponen dalam paralinguistik adalah dialek. Dialek masyarakat Tionghoa dalam berbicara pada umumnya sama walaupun dari suku yang berbeda. Bahasa yang digunakan suku Tio ciu tentu berbeda dengan bahasa suku Hokkien dan lainnya, namun dialeknya akan tetap terdengar sama ditelinga masyarakat yang bukan berasal dari etnis Tionghoa. Kesamaan tersebut antara lain dihasilkan dari bunyi padanan suku kata yang biasa digunakan. Ciri khas lain dalam dialek masyarakat etnis Tionghoa adalah penggunaan konjungsi yang khas seperti "Ha", "Le", "Ma" khususnya pada bagian akhir pengucapan suatu kalimat meskipun kalimat tersebut dalam bahasa Indonesia, sebagai contoh "Berapa harganya ha?", "Mahal le".Selain itu jarangnya penggunaan huruf " $r$ " memberi warna tersendiri pada dialek masyarakat etnis Tionghoa, hal ini bahkan menimbulkan kesan bahwa masyarakat etnis Tionghoa itu cadel atau pelat. Komponen terakhir dalam paralinguistik adalah kecepatan berbicara. Hal ini berdasarkan hasil wawancara dengan para narasumber serta hasil pengamatan langsung peneliti, kecepatan berbicara masyarakat etnis Tionghoa dikategorikan cukup cepat.

c. Penampilan Fisik. Komponen lain dalam penampilan fisik adalah gaya tarik fisik. Gaya tarik fisik masyarakat etnis Tionghoa pada umumnya sama dengan etnis yang berbeda suku. Namun, berdasarkan data yang didapat dilapangan saat penelitian terdapat sedikit perbedaan gaya tarik fisik masyarakat etnis Tionghoa di kota Batam dengan masyarakat etnis Tionghoa yang berasal dari daerah. Hal ini disebabkan oleh perbedaan status sosial serta lokasi yang ditempati. Masyarakat etnis Tionghoa yang tinggal di perkotaan memiliki gaya tarik fisik yang sudah modern.

d. Konsep Ruang. Beberapa masyarakat etnis Tionghoa masih mempercayai pada konsep fengshui dalam penataan ruangan. Konsep ruang terbagi atas dua komponen, diantaranya adalah ruang pribadi dan wilayah interaksional. Sebagian besar masyarakat etnis Tionghoa masih mempercayai tata letak berdasarkan fengshui untuk tempat tinggal baik tata ruang kantor, rumah, bangunan ataupun lokasi bisnis.

e. Konsep Waktu. Konsep waktu mencakup pemilihan waktu untuk mengadakan sebuah acara baik bersifat formal maupun non formal. Masyarakat etnis Tionghoa menentukan hari baik sebagai tanggal dalam menyelenggarakan hari besar, misalnya dalam pernikahan, pindah rumah, maupun peresmian toko. Pemilihan hari diserahkan kepada petua etnis Tionghoa yang diyakini mengerti tentang filosofi pemilihan hari tersebut. 
Selain konsep waktu, masyarakat etnis Tionghoa juga menjaga komitmen terhadap waktu. Sebagai contoh, pada saat peneliti membuat janji wawancara kepada narasumber. Narasumber datang lebih awal, hal ini dirasa bahwa masyarakat etnis Tionghoa menghargai waktu. Komitmen terhadap waktu juga bisa dilihat dalam kegiatan seharihari nya. Perniagaan atau toko yang dimiliki oleh masyarakat etnis Tionghoa biasanya buka dan tutup pada jam yang sudah ditentukan. Masyarakat etnis Tionghoa mematuhi rutinitas, mereka berpegang teguh pada jawdal yang sudah tertata. Kebiasaan sederhana ini membawa banyak manfaat serta menjadikan kebiasaan masyarakat etnis Tionghoa untuk konsisten terhadap waktu serta menjadi pribadi yang disiplin.

f. Warna. Etnis Tionghoa identik dengan berbagai warna. Terbukti setiap perayaan imlek selalu didominasi dengan warna merah. Mulai dari dekorasi rumah, lampion hingga kertas angpao semuanya serba merah. Filosofi warna merah adalah menggambarkan keadaan yang terang dan ceria dalam kehidupan masyarakat etnis Tionghoa. Selain warna merah, masyarakat etnis Tionghoa juga menyemarakkan imlek dengan warna kuning keemasan. Warna kuning keemasan dalam filosofinya menggambarkan harapan di tahun yang baruakan mendatangkan rejeki yang lebih lancar. Oleh karena itu warna merah dan kuning keemasan menjadi warna pakaian khas dalam perayaan imlek. Walaupun demikian, masyarakat etnis Tionghoa tidak dilarang menggunakan warna lain selain merah dan kuning keemasan.

g. Artefak. Berbagai benda peninggalan berupa bangunan, patung, serta benda-benda yang dianggap sebagai sejarah etnis Tionghoa masih dilestarikan hingga saat ini. Salah satu peninggalan sejarah etnis Tionghoa adalah kapal golden cengho yang merupakan kapal replika cengho serta monumen laksamana cengho. Dari wawancara serta pengamatan peneliti, selain sebagai pengingat sejarah, monumen laksamana cengho yang berlokasi di Bengkong laut saat ini juga menjadi salah satu objek wisata kota Batam.

\section{Komunikasi Antar etnis}

Masyarakat etnis Tionghoa di kota Batam memiliki sikap toleransi yang tinggi terhadap etnis sesama nya mau pun antara etnis berbeda sekitarannya. Pentingnya menjalin komunikasi antarbudaya antara masyarakat etnis Tionghoa dengan masyarakat etnis lainnya di kota Batam demi mewujudkan keharmonisan dan saling penerimaan dalam kehidupan sosial budaya satu dengan yang lainnya. Mempelajari bahasa Indonesia dan bahasa- bahasa daerah lainnya menunjukan bahwa masyarakat etnis Tionghoa berbaur dengan etnis lainnya. 
Bermacam upaya yang sudah dilakukan oleh masyarakat etnis Tionghoa kota Batam dalam menjalin komunikasi antar etnis dalam mewujudkan keharmonisan dan saling penerimaan. Berbagai kegiatan sosial yang melibatkan masyarakat umum dari beragam etnis lain yang selama ini sudah diadakan dan menjadi agenda tetap oleh organisasi PSMTI dan BMTI. Kegiata-kegiatan tersebut selain merupakan bentuk kepedulian terhadap masyarakat, juga upaya pengenalan budaya untuk memperkaya pengetahuan bersama serta memelihara kerukunan hidup masyarakat antar etnis di kota Batam

\section{KESIMPULAN}

Berdasarkan hasil penelitian yang dilakukan oleh peneliti tentang perilaku komunikasi etnis Tionghoa kota Batam (analisis fenomenologi komunikasi), maka ada beberapa hal yang perlu disimpulkan antara lain sebagai berikut :

1. Perilaku komunikasi verbal antar pribadi masyarakat etnis Tionghoa di dalam lingkungan keluarga atau satu suku yang sama pada umumnya banyak menggunakan bahasa etnis masing-masing suku. Adapun penggunaan bahasa Indonesia tetap digunakan untuk beberapa kebutuhan seperti edukasi anak serta sebagai pelengkap dan substitusi beberapa konteks bahasa yang tidak ditemukan padanannya dalam bahasa etnis. Di sisi lain ketika berinteraksi dengan orang beretnis Tionghoa yang berbeda suku, penggunaan bahasa Indonesia menjadi lebih dominan. Perilaku komunikasi verbal di lingkungan internal organisasi PSMTI dan BMTI kebanyakan menggunakan bahasa Indonesia, khususnya komunikasi dalam bentuk tertulis. Namun penggunaan bahasa etnis masih tetap digunakan khususnya bahasa suku Tio ciu sebagai suku yang mayoritas. Sementara dalam konteks komunikasi eksternal organisasi, penggunaan bahasa Indonesia menjadi sangat mutlak.

2. Perilaku komunikasi non verbal masyarakat etnis Tionghoa di kota Batam selain terbentuk dari kebudayaan asli leluhur di tanah asalnya, juga merupakan hasil akulturasi dengan kebudayaan lokal di Indonesia. Perilaku komunikasi non verbal tersebut juga mencerminkan karakter budayanya. Perilaku komunikasi non verbal tersebut dibedakan menjadi tujuh bentuk, sebagai berikut:

a. Bahasa Tubuh, yang sering digunakan masyarakat etnis Tionghoa, yaitu gerakan mengepalkan kedua telapak tangan ketika memberi salam serta gerakan menundukkan kepada sebagai simbol menghormati orang yang lebih tua.

b. Paralinguistik, bentuk paralinguistik yang mudah dikenali yaitu dialek yang masih kental merujuk pada bahasa etnis masing-masing suku Tionghoa. Selain itu masyarakat etnis Tionghoa sering menambahkan konjungsi yang menjadi ciri khas pada akhiran 
pengucapan kalimat, baik itu dalam bahasa etnis maupun bahasa Indonesia. Kecepatan berbicara masyarakat etnis Tionghoa tergolong cepat.

c. Penampilan fisik, gaya busana masyarakat etnis Tionghoa saat ini sudah modern mengikuti perkembangan jaman. Walaupun demikian, pakaian adat tradisional tetap dikenakan pada perayaan hari besar.

d. Konsep Ruang, bentuk konsep ruang yang masih dipercayai oleh masyarakat etnis Tionghoa yaitu menata ruang pribadi serta tempat berbisnis berdasarkan fengshui. Beberapa ornamen seperti lukisan dengan objek delapan ekor kuda serta ikan koi diyakini dapat mendatangkan rejeki yang melimpah. Selain itu, masyarakat etnis Tionghoa kota Batam merasa lebih praktis menyewa gedung atau ruangan di hotel guna mengadakan acara seperti resepsi pernikahan.

e. Konsep waktu, bentuk konsep waktu masyarakat etnis Tionghoa yaitu pemilihan hari baik pada saat pindah rumah ataupun perencanaan untuk menggelar resepsi pernikahan. Masyarakat etnis Tionghoa kota Batam disiplin serta bisa mengatur waktu dengan baik.

f. Warna, warna merah diyakini oleh masyarakat etnis Tionghoa mempunyai arti kegembiraan. Kemudian warna kuning emas mempunyai dimaknai dengan kekayaan. Kedua warna tersebut menjadi warna khas dalam perayaan imlek.

g. Artefak, selain patung serta monumen, bentuk artefak lain masyarakat etnis Tionghoa adalah aksesoris tubuh seperti kalung benang merah dengan liontin "pa kua" serta gelang dari benang warna-warni yang sudah didoakan.

3. Perilaku komunikasi antar etnis

Realitas yang tidak bisa dipungkiri adalah bangsa Indonesia merupakan bangsa yang prularisme. Keanekaragaman suku, ras, agama, bahasa, budaya serta adat istiadat merupakan kekayaan bangsa Indonesia yang harus kita syukuri. Mempelajari perilaku komunikasi antar etnis bertujuan untuk menghindari kesalahpahaman dalam berkomunikasi, terciptanya keterbukaan dan penerimaan serta menjadikan sebuah fenomena untuk mengenal beragam kebiasaan adat dan budaya yang berbeda. Dalam menciptakan suatu keharmonisan kehidupan sosial, sangat diperlukan upaya- upaya komunikasi antar etnis yang intensif dan bekesinambungan. Keharmonisan antara masyarakat etnis Tionghoa dengan etnis lainnya di kota Batam tetap harus dijaga dengan mempelajari masing-masing perilaku komunikasi etnis. 


\section{DAFTAR PUSTAKA}

Barth, Fredrik. (1970). Introduction. Dalam Fredrik Barth dkk, Ethnic Group and Boundaries: The Social Organization of Culture Difference. Bergen - Oslo. Universiets Forlaget.

Dinas Kependudukan Kota Batam, (2015). Jumlah Penduduk Kota Batam 2015: Lampiran Data Jumlah Penduduk Berdasarkan Kecamatan. skpd.batamkota.go.id/kependudukan/data-kependudukan.html. Oktober, 15, 2015.

Daymon, Christine, dan Immy Holloway (2008). Metode-metode Riset Kualitatif dalam public relations dan marketing communication.Penerbit Bentang, Yogyakarta

Green, Lawrence W dan Marchel W Kreuter (1991). Health Promoting Planning an educational and environmental approach. Second Edition. Mayfield Publishing Company: Mountain View.

Ichwnudin, (1998). Hubungan Perilaku Komunikasi Peserta Kelompok Penggerak Koentjaraningrat (2007). Manusia dan Kebudayaan Di Indonesia . Djambatan, Jakarta.

Kuswarno, Engkus (2009). Fenomenologi. Widya padjajaran. Bandung:

Larry A. Samovar dan Richard E. Porter (1991). Communication Between Culture. Wadsworth, Belmont, California.

Melly G Tan. (2008). Etnis Tionghoa di Indonesia. Yayasan Obor Indonesia, Jakarta

Miles, Mathew B. Michael Huberman.(1984). Qualitative Data Analysis :A Sourcebook of New Methods. Sage Publication, Inc. London.

Mulyana, Dedi. (2005). Ilmu Komunikasi Suatu Pengantar. Remaja Rosdakarya,Bandung.

M. Moefad, (2007), Perilaku individu dalam masyarakat kajian komunikasi social, el-DeHA Press Fakultas Dakwah IKAHA, Jombang.

Nina W. Syam, M.S (2011). Psikologi sebagai akar ilmu komunikasi. Simbiosa Rekatama Media, Bandung.

Poesponegoro, Marwati Djoened danNugroho Notosusanto (2008). Sejarah Nasional Indonesia II (Edisi Pemutakhiran). PT. Balai Pustaka, Jakarta.

Riswandi, Ilmu Komunikasi. ed. pertama. Yogyakarta: Graha Ilmu, 2009.

Samovar, Porter and McDaniel (2010). Komunikasi Lintas Budaya (Edisi 7). Salemba Humanika, Jakarta.

Sudarmanti. Rini. 2006. "Memahami "Fenomenologi" Kesadaran Intersubjectif Aldfred Schutz". Jakarta: PT Gramedia.

Syamsu, Yusuf (2007). Psikologi Perkembangan Anak \& Remaja. Remaja Rosdakarya.Bandung. 